\title{
TELAAH KEARIFAN LOKAL TERHADAP AKUNTABILITAS LUMBUNG DESA
}

\author{
Yunus Harjito \\ Fakultas Ekonomi, Universitas Setia Budi Surakarta \\ yunus_accounting@yahoo.co.id \\ Ambang Cahyo Wibowo \\ Fakultas Ekonomi dan Bisnis, Universitas Sebelas Maret Surakarta \\ ambangcahyo@gmail.com \\ Djoko Suhardjanto \\ Fakultas Ekonomi dan Bisnis, Universitas Sebelas Maret Surakarta \\ djoko.suhardjanto@yahoo.com
}

\begin{abstract}
This research aims to understand the business of Lumbung Desa Paceklik which based on society's local wisdom, examining governance, and compare between governance implementation and the governance characteristics by the UNDP. One of the most important aspects in governance practice is accountability. Accountability is implemented as the efforts to maintain the Lumbung Desa Paceklik existence. The accounting practice in Lumbung Desa Paceklik is one measure of accountability implementation. The research data were collected by observation and documentation of related information, gradual interviews, and focus group discussion (FGD). The study was conducted from the beginning of April 2013 until early March 2014 in the Dempel village, Geneng subdistrict, Ngawi district, East Java. The results explained that the governance of the Lumbung Desa Paceklik is quiet well to do. Based on the governance characteristics by UNDP, only the rule of law which is still an obstacle. Moreover, the accountability is interpreted not only as an liability, but also as a need to maintain the Lumbung Desa Paceklik's existence. Implementation of accounting was not optimal due to the limited understanding and ability of the board to the theory and practice of ideal accounting practice.
\end{abstract}

Keywords: accountability, accounting, governance, lumbung desa paceklik, and rule of law.

\begin{abstract}
ABSTRAK
Penelitian ini bertujuan untuk memahami bisnis Lumbung Desa Paceklik yang berbasis kearifan lokal masyarakat, memeriksa tata kelola, dan membandingkan antara pelaksanaan pemerintahan dan karakteristik pemerintahan oleh UNDP. Salah satu aspek yang paling penting dalam praktek tata kelola adalah akuntabilitas. Akuntabilitas diimplementasikan sebagai upaya untuk mempertahankan keberadaan Lumbung Desa Paceklik. Praktek akuntansi di Lumbung Desa Paceklik merupakan salah satu ukuran
\end{abstract}


pelaksanaan akuntabilitas. Data penelitian dikumpulkan melalui observasi, dokumentasi informasi terkait, wawancara bertahap, dan focus group discussion (FGD). Penelitian dilakukan dari awal April 2013 sampai dengan awal Maret 2014 di desa Dempel, Kecamatan Geneng, Kabupaten Ngawi, Jawa Timur. Hasil penelitian menjelaskan bahwa tata kelola Lumbung Desa Paceklik cukup baik dilakukan. Berdasarkan karakteristik pemerintahan oleh UNDP, hanya aturan hukum yang masih menjadi kendala. Selain itu, akuntabilitas diartikan tidak hanya sebagai kewajiban, tetapi juga sebagai kebutuhan untuk mempertahankan keberadaan Lumbung Desa Paceklik ini. Pelaksanaan praktik akuntansi tidak optimal karena terbatasnya pemahaman dan kemampuan pengelola tentang teori dan praktik-praktik akuntansi yang ideal.

Kata kunci: akuntabilitas, akuntansi, tata kelola, lumbung desa paceklik, dan aturan hukum

\section{PENDAHULUAN}

Ketahanan pangan merupakan salah satu isu strategis dalam konteks pembangunan negara sebagai negara berkembang, karena memiliki fungsi ganda yaitu sebagai salah satu sasaran utama pembangunan dan salah satu instrumen utama pembangunan ekonomi (Simatupang 1999). Untuk menjaga stabilitas ketahanan pangan antar waktu atau musim, maka perlu adanya kebijakan yang bertujuan melibatkan masyarakat dalam fungsi mekanisme penyeimbang logistik tradisional yang dikenal dengan nama lumbung desa. Selama ini lembaga logistik tradisional tersebut terpinggirkan karena adanya intervensi kelembagaan modern yang diakselerasi keberadaannya oleh pemerintah seperti Bulog dan KUD, padahal lumbung desa merupakan institusi lokal yang dulu cukup efektif dalam menjaga ketahanan pangan masyarakat secara swadaya (Soemaryani et al., 2009).

Lumbung desa disebut juga bank padi atau bank gabah (istilah padi dalam bahasa jawa) yang bertujuan memberikan pinjaman kepada petani pada bulan-bulan sebelum panen dimana persediaan padi sangat sedikit dan harganya relatif tinggi, selain itu bertujuan untuk mengurangi kebiasaan buruk penduduk yang menjual hasil panen secara besar-besaran kepada tengkulak (Wasino et al., 2007). Selain berfungsi sebagai bank padi, lumbung desa merupakan salah satu prototipe Social Safety Net atau jaminan sosial bagi petani dari ancaman kelaparan (Soemaryani, Kartib, \& Setiawan 2009). Sejauh ini masih terdapat lumbung desa yang dikelola oleh masyarakat, salah satunya adalah Lumbung Desa Paceklik Desa Dempel, selanjutnya disebut Lumbung Paceklik yang merupakan satu-satunya Lumbung Desa di Kecamatan Geneng, Kabupaten Ngawi. Lumbung desa tersebut masih bersifat sangat tradisional, sederhana, masih asli dan menjadi kebanggaan bagi masyarakat Desa Dempel yang telah berusia kurang lebih 65 tahun.

Lumbung Paceklik sebagai organisasi publik non pemerintah menjadi unik dan menarik karena meskipun beroperasi seolah-olah seperti bank gabah, namun dalam praktiknya tidak membagikan keuntungannnya bagi masyarakat yang menanamkan 
modal gabahnya pada awal pembentukan lumbung. Hasil perolehan usaha digunakan untuk menambah jumlah gabah yang diputar lagi agar dapat dipinjam seluruh masyarakat dan tidak hanya yang memiliki sawah garapan saja. Ini merupakan ciri atau bentuk kearifan lokal masyarakat Desa Dempel yang tidak mementingkan kepentingan pribadi untuk mengejar kemakmuran sekelompok orang, namun untuk kemakmuran seluruh warga desa. Keuntungan tidak dibagikan secara langsung kepada penyetor modal. Dengan demikian, akuntabilitas menjadi hal penting bagi setiap organisasi tidak terkecuali Lumbung Paceklik. Akuntabilitas yang tinggi akan menumbuhkan kepercayaan masyarakat serta pemangku kepentingan lainnya yang ingin membantu ataupun akan bekerjasama dengan Lumbung Paceklik. Akuntabilitas juga merupakan hak masyarakat atau kelompok dalam masyarakat yang timbul karena adanya hubungan antara organisasi dan masyarakat (Gray et al., 2006).

Sebagai lembaga logistik tradisional yang telah ada sejak tahun 1902 Hartatik (2010), tentunya terdapat suatu mekanisme pengelolaan yang dijalankan agar organisasi lumbung dapat bertahan hingga saat ini. Mekanisme pengelolaan lumbung tentunya tidak terlepas dari adanya hambatan-hambatan. Beberapa hambatan yang dialami diantaranya kesulitan dalam administrasi pembukuan, kurangnya kesadaran dalam pengembalian pinjaman, adanya penyusutan dalam penyimpanan yang disebabkan oleh rendahnya mutu gabah yang disetor, adanya pengurus yang tidak jujur, kurangnya kerja sama antar pengurus serta kurangnya pembinaan dari pemerintah (Yanto 1994). Pengelolaan yang kurang baik yang disebabkan karena pengurusnya tidak cakap dan tidak baik dapat menyebabkan kemunduran dari lumbung desa dan bahkan lenyap (Nugrahananto et al., 2008).

Keberadaan lumbung desa yang saat ini sulit sekali ditemukan, menjadi menarik untuk diteliti mengingat pada masa lalu lembaga ini memiliki fungsi dan peranan yang sangat besar dalam perkonomian desa (Noval 2002). Pada kondisi saat ini, lumbung desa dapat menjadi unggulan bagi hasil pertanian khususnya padi. Banyak penelitian mengenai akuntabilitas pada organisasi nirlaba publik non pemerintah (Non Governance Organization) diantaranya adalah Gray et al. (2006), akuntabilitas organisasi nirlaba seperti Center for Services for Voluntary Organizatian atau CSVs di Italia yang dilakukan oleh Costa et al. (2011), penelitian akuntabilitas organisasi keagamaan seperti Gereja oleh Laughlin (1988, 1990) serta (Duncan \& Flesher 2002). Dalam konteks kondisi di Indonesia yang secara geografis adalah negara agraris dan sudah mengembangkan lumbung desa, maka akuntabilitas lembaga tersebut menjadi hal yang menarik untuk dikaji dan dianalisis. Penelitian mengenai akuntabilitas lembaga lumbung desa ini dilakukan dengan mengkaji dan menganalisis tata kelola Lumbung Paceklik yang merupakan kearifan lokal masyarakat Desa Dempel.

Tata kelola yang baik (good governance) diperlukan dalam setiap organisasi agar dapat mencapai tujuan yang ditetapkan dan menjaga kesinambungan hidupnya baik dalam jangka pendek maupun jangka panjang. Lumbung desa sebagai lembaga publik non pemerintah tentunya tidak bisa dipisahkan dari peran praktik terbaik tata kelola yang 
diselaraskan dengan kearifan lokal agar organisasi ini dapat mencapai tujuannya dan menjaga kesinambungan hidupnya hingga saat ini. Kearifan lokal yang dalam kebahasaan berarti kearifan setempat (local wisdom), dapat dipahami sebagai gagasan-gagasan lokal yang bersifat bijaksana, penuh kearifan dan bernilai yang tertanam dan diikuti oleh warga masyarakatnya (Kartawinata 2011).

Peran lumbung desa atau bank padi sebagai social safety nets bagi masyarakat pedesaan tidak akan maksimal jika tidak didukung oleh tata kelola yang baik. Oleh karena itu, penelitian ini berupaya untuk memaparkan dan memahami tata kelola lumbung desa yang berakar dari kearifan lokal yang dalam tata kelola tersebut terdapat prinsip good governance diantaranya akuntabilitas. Peran akuntansi dalam akuntabilitas lumbung desa juga menjadi sangat menarik untuk diungkap guna pengembangan lumbung desa sebagai sistem ketahanan pangan bagi masyarakat pedesaan.

Selain itu untuk mengetahui bagaimana akuntabilitas dimaknai sebagai bagian dari upaya untuk mempertahankan eksistensi Lumbung Paceklik serta menemukan suatu pemahaman bagaimana praktik akuntansi dijalankan dalam pengelolaan Lumbung Paceklik sebagai bagian dari wujud akuntabilitas. Temuan yang diperoleh diharapkan dapat memberi kontribusi bagi perumus kebijakan dalam rangka pengembangan lumbung desa sebagai sistem ketahanan pangan masyarakat pedesaan. Kajian ini juga diharapkan dapat memberi sumbangsih dalam pengembangan organisasi lumbung desa khususnya Lumbung Paceklik, terutama yang berkaitan dengan akuntabilitas, sehingga lumbung desa menemukan pola tata kelola yang sesuai dengan keadaan, budaya serta tradisi masyarakat yang ada, tentunya dengan memberi nilai tambah bagi seluruh pemangku kepentingan Lumbung Paceklik.

Lebih lanjut penelitian ini diharapkan dapat menambah wawasan bahwa penggunaan ilmu akuntansi yang telah ada sangatlah luas dan dapat masuk dalam domain pertanian dan sosiologi. Kajian ini diharapkan dapat memberi sumbangsih dalam pengembangan organisasi lumbung desa khususnya Lumbung Desa Paceklik Desa Dempel, terutama yang berkaitan dengan akuntabilitas sehingga lumbung desa menemukan pola tata kelola yang sesuai dengan keadaan, budaya serta tradisi masyarakat yang ada, tentunya dengan memberi nilai tambah bagi seluruh pemangku kepentingan Lumbung Desa Paceklik Desa Dempel.

\section{KAJIAN PUSTAKA DAN PERUMUSAN HIPOTESIS}

\section{Lumbung Desa}

Lembaga lumbung desa diawali dari tradisi di daerah penghasil padi di Jawa yang telah ada sebelum Perang Dunia II (Wiradi 1985). Pada musim panen setiap petani dianjurkan menyimpan sebagian padinya dalam apa yang disebut lumbung desa dengan tujuan ketika musim paceklik, mereka yang mempunyai simpanan boleh meminjam padi dari lumbung desa, dengan kewajiban mengembalikannya pada waktu panen yang 
disertai sejumlah padi tambahan sebagai bunga antara 25-30 persen semusim. Dengan cara tersebut diharapkan dalam jangka waktu tertentu persediaan padi lumbung desa menjadi bertambah besar sehingga pada saatnya bukan saja para penyimpan tetapi mereka yang tidak memiliki simpanan seperti buruh tani dapat meminjam dari lumbung desa. Pada tahun 1912, tradisi tersebut dilembagakan oleh pemerintah kolonial Belanda dan pengelolaannya dibawah lembaga kredit pemerintah yang disebut Volkscredietwezen.

Wasino (2004) mengemukakan bahwa di daerah Grobogan, lumbung desa telah ada sejak tahun 1902 di Distrik Kradenan. Berdirinya lumbung desa merupakan ide dari pemerintah lokal sebagai reaksi atas kondisi sosial ekonomi penduduk yang memprihatinkan karena adanya kebiasaan menjual hasil panen secara besar-besaran kepada pedagang Cina pada saat panen tiba tanpa menyisakan bahan pangan untuk musim tanam berikutnya. Model penjualan tersebut sangat merugikan petani karena harga jual padi pada musim panen sangat murah, sedangkan pada musim paceklik, petani banyak terlilit hutang dengan bunga yang mencapai 200-300 persen per tahun. Nugrahanto et al. (2008) menjelaskan bahwa keberadaan lumbung desa dapat menurunkan bunga pinjaman padi di luar usaha lumbung desa, dapat menekan kenaikan harga penjualan padi saat paceklik, memperbaiki keuangan kas desa dengan menyerahkan kelebihan uang kas lumbung ke desa dan menambah modal bank desa yang bersumber dari cadangan kekayaan lumbung desa.

Dalam penelitiannya di daerah Watugede, Kemusu, Boyolali, Wibowo et al. (2007) menjelaskan bahwa sejak dulu sudah ada kelembagaan dalam bidang ekonomi yang disebut "Lumbung Desa". Lembaga ekonomi tersebut berakar pada nilai budaya dan rasa kesetiakawanan dengan fungsi untuk mengembangkan distribusi hasil panen secara adil. Lembaga ini diharapkan juga mampu mencegah munculnya kesenjangan ekonomi yang berlebihan, meminimalkan kecemburuan sosial, mencegah pencurian serta memanfaatkan sumber daya alam secara hati-hati melalui mekanisme adat.

\section{Kearifan Lokal}

Pembentukan dan pengelolaan lumbung desa yang dilandasi oleh hubungan sosial yang kuat dalam kehidupan masyarakat dapat disebut sebagai salah satu perwujudan atas kearifan lokal. Kearifan lokal sendiri menurut Sartini (2004) adalah gagasan-gagasan setempat yang bersifat bijaksana, penuh kearifan, bernilai baik, yang tertanam dan diikuti oleh anggota masyarakatnya. Kearifan lokal terbentuk sebagai keunggulan budaya masyarakat setempat maupun kondisi geografis dalam arti luas. Kearifan lokal merupakan produk budaya masa lalu yang patut secara terus-menerus dijadikan pegangan hidup. Meskipun bernilai lokal tetapi nilai yang terkandung di dalamnya dianggap sangat universal. Kearifan lokal lahir dari learning by experience yang tetap dipertahankan dan diturunkan dari generasi ke generasi yang manfaat utamanya adalah menciptakan keteraturan dan keseimbangan antara kehidupan sosial, budaya, dan kelestarian sumber daya alam (Cahyanto et al., 2012). Pengertian kearifan lokal secara lebih luas diartikan sebagai segala sesuatu yang berkaitan dengan kekhasan budaya-budaya lokal tertentu 
yang harus diakui keberadaannya dan berbeda dengan kekhasan budaya lokal tertentu lainnya (Salam 2006). Salah satu wujud kearifan lokal masyarakat yang masih dilestarikan sampai saat ini adalah Lumbung Desa Paceklik Desa Dempel.

\section{Solidaritas Mekanik}

Selain kearifan lokal, di dalam masyarakat terdapat hubungan-hubungan antar individu maupun kelompok yang didasarkan pada perasaan moral dan kepercayaan yang dianut bersama dan diperkuat oleh pengalaman emosional bersama, inilah yang disebut sebagai konsep solidaritas sosial yang dikemukakan Durkheim (Johnson 1986). Solidaritas mekanik merupakan solidaritas yang tergantung pada individu yang memiliki sifat yang sama dan menganut kepercayaan dan pola normatif yang sama pula, oleh karenanya individualitas tidak berkembang dan terus-menerus dilumpuhkan oleh tekanan yang besar sekali untuk konformitas (Johnson 1986). Solidaritas mekanik biasanya ditemui pada masyarakat yang tinggal di pedesaan, dimana pembagian kerja masih rendah. Maksudnya adalah apa yang dapat dilakukan oleh seorang anggota masyarakat biasanya dapat dilakukan pula oleh orang lain. Ciri khas yang penting dari solidaritas mekanik adalah bahwa solidaritas itu didasarkan pada suatu tingkat homogenitas yang tinggi dalam kepercayaan, sentimen dan sebagainya seperti yang dilakukan oleh masyarakat Desa Dempel.

\section{Governance}

Besarnya harapan masyarakat pedesaan pada suatu lembaga swadaya yang berperan dalam menopang ketahanan pangan tentunya perlu didukung dengan suatu sistem tata kelola yang baik (Maksum 2005). Konsep mengenai tata kelola yang baik ini sering disebut Governance. United Nations Development Programme (UNDP) memberikan beberapa karakteristik mengenai good governance (Mardiasmo 2002) yaitu: participation, rule of law, transperancy, responsiveness, consensus orientation, equity, efficiency and effectiveness, accountability dan strategic vision.

Untuk memahami tata kelola pada Lumbung Paceklik, maka karakteristik governance yang disebutkan UNDP tersebut dilihat implementasinya dalam pengertian berikut: (1) Adanya partisipasi anggota dalam pengambilan keputusan yang dilaksanakan dalam Rapat Anggota Tahunan (RAT) baik partisipasi langsung maupun keterwakilan; (2) Tegaknya supremasi hukum diterjemahkan sebagai adanya kerangka hukum yang mengatur tentang pengelolaan lumbung serta substansi dari aturan tersebut dalam pelaksanaanya tidak membeda-bedakan warga masyarakat yang ada di Desa Dempel; (3) Transparansi diartikan bahwa informasi yang ada dapat diakses oleh seluruh pemangku kepentingan Lumbung Paceklik; (4) Peduli pada stakeholder diterjemahkan bahwa proses pengelolaan lumbung harus berusaha melayani seluruh pihak yang berkepentingan terhadap Lumbung Desa Paceklik; (5) Berorientasi pada konsensus artinya pengelolaan lumbung dapat mengakomodir berbagai kepentingan anggota dengan tetap mengutamakan kepentingan-kepentingan yang lebih besar; (6) Kesetaraan diartikan bahwa dalam pengelolaan Lumbung Paceklik setiap anggota memiliki kesempatan yang 
sama untuk meminjam gabah dan memiliki hak yang sama dalam RAT; (7) Efektifitas dan efisiensi diartikan bahwa pengelolaan Lumbung Paceklik harus memberi manfaat sesuai apa yang diharapkan oleh warga masyarakat Dempel pada umumnnya dan para anggota pada khususnya dengan menggunakan sumber daya yang dimiliki seoptimal mungkin; (8) Akuntabilitas diartikan bahwa para pengambil keputusan dalam hal ini pengurus bertanggungjawab kepada anggota maupun lembaga-lembaga lain yang berkepentingan; dan (9) Visi strategis yaitu adanya pemikiran bahwa Lumbung Paceklik harus dipertahankan dan mampu memberi manfaat yang optimal bagi masyarakat Desa Dempel.

\section{Akuntabilitas}

Akuntabilitas sebagai salah satu prinsip governance berkaitan dengan pertanggunjawaban pimpinan atas keputusan dan hasil yang dicapai, sesuai dengan wewenang yang dilimpahkan dalam pelaksanaan tanggung jawab mengelola organisasi. Akuntabilitas merupakan perwujudan kewajiban seseorang atau unit organisasi untuk mempertanggungjawabkan pengelolaan sumber daya dan pelaksanaan kebijakan yang dipercayakan kepadanya dalam rangka pencapaian tujuan yang telah ditetapkan melalui media pertanggungjawaban berupa laporan akuntabilitas kinerja secara periodik (BPKP 2007). Tolok ukur atau indikator pengukuran kinerja adalah kewajiban individu dan organisasi untuk mempertanggungjawabkan capaian kinerjanya melalui pengukuran yang seobyektif mungkin. Dengan demikian, akuntabilitas akan tumbuh subur pada lingkungan yang mengutamakan keterbukaan sebagai landasan pertanggunjawaban (LAN 2000). Akuntabilitas dalam Lembaga Lumbung Paceklik dipahami sebagai suatu kewajiban pengurus untuk mempertanggunjawabkan sumber daya lumbung desa yang dikelola serta kebijakan yang timbul atas pengelolaan tersebut kepada seluruh pemangku kepentingan pada setiap periode pertanggunjawaban.

Selain itu, Undang-undang Nomor 6 tahun 2014 tentang Desa menyebutkan pada pasal 24 bahwa Penyelenggaraan Pemerintahan Desa berdasarkan asas kepastian hukum, tertib penyelenggaraan pemerintahan, tertib kepentingan umum, keterbukaan, proporsionalitas, profesionalitas, akuntabilitas, efektivitas dan efisiensi, kearifan lokal, keberagaman dan partisipatif. Oleh karena itu, yang menjadi fokus utama pada pembahasan ini adalah masalah kepastian hukum, akuntabilitas, efektivitas dan efisiensi pada implementasi Lumbung Paceklik.

\section{Akuntansi}

Akuntansi dapat dirumuskan dari dua sudut pandang yaitu pemakai jasa akuntansi dan proses kegiatannya. Dari sudut pandang pemakainya, akuntansi didefinisikan sebagai suatu disiplin yang menyediakan informasi yang diperlukan untuk melaksanakan kegiatan secara efisien dan mengevaluasi kegiatan-kegiatan suatu organisasi dimana informasi yang dihasilkan diperlukan untuk membuat perencanaan yang efektif, pengawasan dan pengambilan keputusan oleh manajemen serta pertanggungjawaban organisasi baik itu kepada investor, kreditur, badan pemerintah maupun pemangku 
keptentingan lainnya. Dari sudut pandang kegiatannya, akuntansi didefinisikan sebagai proses pencatatan, penggolongan, peringkasan, pelaporan dan penganalisaan data keuangan suatu organisasi (Jusup 2001).

Akuntansi dalam hal tata kelola Lumbung Paceklik ini dipahami sebagai suatu disiplin yang menyediakan informasi yang diperlukan untuk melaksanakan kegiatan secara efisien dan mengevaluasi kegiatan-kegiatan lumbung desa dimana informasi yang dihasilkan diperlukan untuk membuat perencanaan yang efektif, pengawasan, pengambilan keputusan oleh pengurus serta pertanggungjawaban organisasi kepada anggota maupun pemangku keptentingan lainnya. Penyediaan informasi ini diperoleh melalui proses pencatatan, penggolongan, peringkasan, pelaporan dan penganalisaan data transaksi dan kegiatan ekonomi Lumbung Paceklik. Laporan keuangan utama yang dihasilkan dari proses akuntansi adalah neraca dan laporan laba rugi (Jusup 2001).

Komposisi laporan keuangan pemerintah desa sejatinya juga mengikuti laporan keuangan pemerintah sesuai PSAP nomor 1 paragraf 14 yang menyatakan bahwa laporan keuangan terdiri atas laporan pelaksanaan anggaran (laporan realisasi anggaran, laporan perubahan saldo anggaran lebih), laporan finansial (neraca, laporan operasional, laporan arus kas, laporan perubahan ekuitas, dan catatan atas laporan keuangan).

Pemerintahan desa memiliki keterbatasan sumber daya manusia sehingga hanya menetapkan laporan wajib yang sederhana karena hanya berupa laporan realisasi anggaran yang kemudian turut serta dilampirkan: buku kas umum desa, buku kas pembantu perincian objek pengeluaran, buku kas harian pembantu, laporan realisasi penerimaan alokasi dana desa dan laporan realisasi belanja alokasi dana desa.

\section{METODA PENELITIAN}

Penelitian ini termasuk tipe penelitian kualitatitif dan objek penelitian adalah Lumbung Desa di Desa Dempel, Kecamatan Geneng, Kabupaten Ngawi. Lumbung Desa dalam hal ini bukan terbatas pada bangunan fisik lumbung, tetapi mencakup governance, akuntabilitas dan akuntansi. Waktu penelitian dimulai pada pertengahan April 2013 sampai dengan awal Maret 2014 yang mempertimbangkan saat pemasukan gabah, saat pengeluaran gabah dan saat Rapat Anggota Tahunan (RAT) sehingga diperoleh hasil pengamatan yang lebih lengkap. Wawancara dilakukan secara mendalam terhadap narasumber yang disebut informan yaitu di antaranya para pengurus lumbung desa, mantan pengurus lumbung desa, aparat desa dan anggota lumbung yang berpartisipasi aktif dalam Lembaga Lumbung Paceklik.

\section{Metoda Pengumpulan Data dan Teknik Analisis Data}

Pengumpulan data dilakukan dengan pengamatan, pengumpulan dokumen dan informasi-informasi yang terkait dengan Lumbung Paceklik, wawancara bertahap dan focus group discussion (FGD). Pada dasarnya, proses pengumpulan data juga sebagai 
langkah awal dalam proses analisis data, karena itu setelah data dikumpulkan maka sesungguhnya sekaligus peneliti sudah menganalisis datanya (Bungin 2011).

Menurut Bungin (2011) dua hal yang ingin dicapai dalam analisis data kualitatif yaitu menganalisis proses berlangsungnya fenomena sosial dan memperoleh suatu gambaran yang tuntas terhadap proses tersebut dan menganalisis makna yang ada dibalik informasi, data dan proses suatu fenomena sosial itu. Langkah-langkah analisis data dalam penelitian ini mengacu pada teknik yang dijabarkan oleh Creswell (2012), yaitu: (1) Mengolah dan mempersiapkan data untuk dianalisis; (2) Membaca keseluruhan data; (3) Menganalisis lebih detail dengan mengcoding data, mengolah materi atau informasi menjadi segmen-segmen tulisan; (4) Menerapkan proses coding untuk mendeskripsikan seting, lokasi, orang-orang, kategori-kategori dan tema-tema yg akan dianalisis; (5) Menyajikan kembali deskripsi dan tema-tema yang diperoleh dalam bentuk narasi atau laporan kualitatif; (6) Menginterpretasi atau memaknai data yang berasal dari perbandingan antara hasil penelitian dengan informasi yang berasal dari literatur atau teori.

\section{Pembentukan Lumbung Desa dan Kearifan Lokal}

Sejarah pembentukan Lumbung Paceklik ini diawali dengan keprihatinan pemimpin desa dan tokoh masyarakat Desa Dempel sekitar tahun 1951. Lumbung Desa Paceklik Desa Dempel dibentuk pada masa kepemimpinan Lurah Kamari sebagai Kepala Desa tahun 1951-1970. Pada mulanya petani kesulitan modal pada saat musim tanam serta untuk menanggulangi musim paceklik. Oleh karenanya, pada saat itu setiap kuli kenceng (yaitu orang-orang yang diberi kepercayaan oleh pemerintah desa untuk mengelola tanah desa dan diberi tugas untuk megerjakan pekerjaan dari desa, misalnya memperbaiki jalan desa yang rusak. Sebagai imbalan, diberi hak untuk mengolah tanah garapan berupa sawah) diwajibkan menyetorkan gabah untuk pembentukan modal lumbung. Selanjutnya modal tersebut dipinjamkan kepada masyarakat kuli kenceng yang menghadapi musim paceklik. Karena perkembangan yang cukup baik, maka sasaran peminjaman diperluas ke masyarakat kuli setengah (yaitu orang-orang yang diberi tugas mengerjakan pekerjaan desa dan memperoleh imbalan tanah garapan berupa tegalan) dan selanjutnya kepada seluruh masyarakat Desa Dempel, seperti informasi yang diperoleh dalam wawancara berikut:

\footnotetext{
“Asal mulanya itu oleh Pak Lurah Kamari, yang berakhir jabatan tahun 1970, pada waktu itu, tiap kuli kenceng, yaitu masyarakat yang wajib bekerja untuk pemerintah desa dengan upah sawah garapan, ditarik gabah yang hanya sekali penyetoran untuk modal awal Lumbung Desa....”

“.....akhirnya karena padi itu masih ada sisa setelah dipinjamkan ke kuli kenceng dan kuli setengah, akhirnya semua masyarakat bisa pinjam dengan catatan sudah lunas semua hutangnya..." (Hasil wawancara dengan informan pada tanggal 21 Desember 2013.
}

Keuntungan dari operasi lumbung tidak dinikmati secara langsung oleh para penyetor modal awal. Mereka tidak mengharapkan imbalan hasil tersebut sebagai 
keuntungan ekonomis bagi mereka, namun ditujukan agar Lumbung Paceklik dapat berkembang yang pada akhirnya memberikan manfaat yang maksimal bagi seluruh masyarakat Desa Dempel, seperti yang dikemukakan dalam wawancara berikut:

“......terus yang dulu menanam saham di situ sudah tidak mengurus. Ibarat modal pertama menjadi hibah lumbung desa dari orang-orang kaya di desa. Motivasinya tidak untuk memperoleh hasil, tapi murni untuk modal bergulir. Penyertaan modal anggota baru yang mau pinjam sudah tidak ada." (Hasil wawancara dengan informan tanggal 07 September 2013.

“.....sangat merasakan peran dari keberadaan kegiatan lumbung ini dan dalam diri warga masyarakat Dempel timbul perasaan bahwa saya juga memiliki lumbung, lumbung ini untuk membantu kebutuhan saya juga dan ketika saya tidak tertib maka saya tidak akan memperoleh manfaat maksimal dari lumbung...”. (Pernyataan informan saat wawancara 22 Desember 2013.

Informasi-informasi tersebut jelas menggambarkan bentuk kearifan lokal masyarakat Desa Dempel, yang sesuai dengan definisi (Sartini 2004). Sejalan dengan perkembangannya, Lumbung Paceklik telah memilliki 830 anggota yang terdiri dari 325 anggota berada di Dusun Dempel, 310 anggota dari Dusun Nglencong dan 195 anggota dari Dusun Gunting. Jumlah gabah yang dikelola sampai dengan tahun 2013 sebesar $101.477,5 \mathrm{~kg}$ atau 101,5 ton.

\section{Governance Lumbung Desa Paceklik Desa Dempel}

Mekanisme pengelolaan yang baik terhadap Lumbung Paceklik dimaksudkan agar lumbung dapat beroperasi secara berkesinambungan dan memberi manfaat yang optimal bagi masyarakat Desa Dempel. Oleh karena itu sistem pengelolaan yang dilakukan haruslah adil, transparan, akuntabel, serta memiliki mekanisme pertanggungjawaban yang jelas agar dapat memenuhi harapan bagi para pemangku kepentingan Lumbung Paceklik. Untuk mengetahui bagaimana governance dilaksanakan dalam pengelolaan Lumbung Paceklik, berikut ini akan dibahas karakteristik good governance yang telah dijelaskan dalam pembahasan sebelumnya.

\section{Adanya Partisipasi Masyarakat}

Partisipasi masyarakat nampak dalam setiap kegiatan lumbung di antaranya saat pengeluaran gabah, pemasukan gabah hingga RAT. Dalam RAT, pengurus tidak mengundang seluruh anggota yang berjumlah 840 orang, tetapi melalui keterwakilan yang dianggap oleh pengurus mampu mewakili aspirasi maupun mewakili wilayah. Masyarakat dapat berperan aktif sebagai pengurus yang menjalankan pengelolaan lumbung. Sebagai anggota, masyarakat Desa Dempel berperan dalam memilah dan memilih pengurus yang dianggap cakap dan mampu dalam mengelola lumbung. Peran sebagai anggota dapat juga ditunjukkan dalam melakukan evaluasi terhadap kinerja pengurus, menilai laporan pertanggungjawaban, serta berperan dalam memberikan rekomendasi-rekomendasi pada saat RAT sebagai dasar kebijakan pengurus dalam mengelola lumbung pada periode selanjutnya. 


\section{Tegaknya Supremasi Hukum}

Tegaknya supremasi hukum diartikan sebagai adanya kerangka hukum yang mengatur tentang pengelolaan lumbung serta substansi dari aturan tersebut dalam pelaksanaanya tidak membeda-bedakan warga masyarakat yang ada di Desa Dempel. Dalam aturan tertulis yang tercantum dalam akta pendirian Lumbung Paceklik sebagai Yayasan Kesejahteraan Masyarakat tanggal 18 Maret 1991 Nomor 46 disebutkan bahwa tujuan organisasi tersebut adalah meningkatkan kesejahteraan hidup serta sosial ekonomi para anggota masyarakat di wilayah Desa Dempel, Kecamatan Geneng, Kabupaten Ngawi. Pembentukan badan hukum yang sesuai bagi Lumbung Paceklik merupakan salah satu permasalahan yang harus diselesaikan mengingat dengan adanya bentuk badan hukum yang jelas dan sesuai maka akan memudahkan pengelolaannya dan juga memudahkan dalam melakukan aktivitas hukum dengan subyek hukum lainnya, misalnya untuk mengajukan bantuan kepada pemerintah dalam rangka revitalisasi bangunan lumbung. Hal tersebut menjadi harapan bagi pengurus yang dijelaskan dari hasil wawancara berikut:

\footnotetext{
"Keterbatasan kita dalam bentuk badan hukum. Ketika mau mengajukan bantuan yang bersumber dari APBD/APBN harus berbentuk badan hukum. Padahal kondisi bangunan fisik lumbung perlu perhatian, dari dulu saya sebelum lahir sampai saat ini saya menjadi pengurus tidak berubah." (Hasil wawancara dengan informan tanggal 07 September 2013.

“...kalau lumbung dari dulu itu memang desa tidak bisa ikut campur, karena bukan BUMDes. Lumbung itu berasal dari perkumpulan warga masyarakat sendiri, tidak ada aset desa masuk ke sini (lumbung). Jadi campur tangan desa hanya karena ini bertempat di wilayah desa dempel, tetapi bukan milik pemerintah desa. Kalau perangkat desa ikut campur mengelola, karena pemimpin wilayah, dan ketika menyampaikan ke masyarakat lebih didengarkan. Kalau soal bantuan, memang kita tidak tahu pasti bentuk organisasi, kita bukan BUMDes, Koperasi juga bukan, kita itu lembaga apa? Tetapi kenyataanya berjalan hingga saat ini. Pemerintah mau turun ke sini juga bingung, ini mau dikategorikan ke dalam apa ketika menyalurkan bantuan. Karena kita swadaya masyarakat murni." (Pernyataan informan saat FGD tanggal 15 September 2013.
}

Legalitas tentang eksistensi Lumbung Paceklik saat ini masih belum jelas karena atribut bentuk badan hukum yang ada menurut aturan yang berlaku saat ini belum diperbarui. Untuk sementara waktu agar pengelolaan lumbung tidak mengalami kekosongan aturan, para pengurus masih menggunakan Anggaran Dasar Organisasi yang tercantum dalam akta pendirian yayasan sebagai dasar aturan pengelolaan lumbung.

\section{Transparansi}

Transparansi dalam hal ini diartikan bahwa informasi yang berkaitan dengan Lumbung Paceklik dapat diakses oleh seluruh pemangku kepentingan. Informasi tersebut diantaranya jumlah gabah yang tersedia untuk dipinjamkan kepada anggota, penggunaan dana operasional, serta infomasi lainnya yang berkaitan dengan Lumbung Paceklik. Salah satu cara yang dilakukan pengurus untuk mempermudah akses informasi selain pada 
waktu RAT adalah dengan menginformasikan kondisi lumbung kepada pengurus yang bukan bagian administrasi.

\section{Peduli pada Stakeholder}

Pengelolaan lumbung desa paceklik peduli terhadap para pemangku kepentingan, terutama anggota yang dibuktikan dengan kemudahan memperoleh pinjaman gabah serta layanan berupa surat untuk mengingatkan anggota berkenaan dengan pinjaman. Selain itu, Lumbung Desa Paceklik juga berkontribusi terhadap pembangunan Desa Dempel dengan menyerahkan sebagian hasil kegiatan lumbung periode tahun 2013 untuk menambah Pendapatan Asli Desa berupa uang Rp500.000,00 yang tercantum dalam Laporan Pertanggungjawaban Lumbung Tahun 2013 Masa Bakti 2013-2015. Hasil temuan tersebut juga menginformasikan bahwa keberadaan Lumbung Paceklik memberikan manfaat yang sangat berarti bagi kehidupan masyarakat Desa Dempel.

\section{Berorientasi pada Konsensus}

Berorientasi pada konsensus diartikan bahwa pengelolaan lumbung dapat mengakomodir berbagai kepentingan masyarakat Desa Dempel, khususnya anggota dengan tetap mengutamakan kepentingan-kepentingan yang lebih besar. Sebelum kepengurusan tahun 2013, keadaan lumbung dapat dikatakan dalam keadaan kritis. Para anggota lumbung yang juga masyarakat Desa Dempel merasa prihatin atas kondisi lumbung. Demi kepentingan bersama, melalui Badan Perwakilan Desa masyarakat mendorong Pemerintah Desa untuk membangkitkan dan menyehatkan kembali Lumbung Paceklik sebagai lembaga yang banyak memberi manfaat bagi kehidupan masyarakat Desa Dempel.

\section{Kesetaraan}

Kesetaraan diartikan bahwa dalam pengelolaan Lumbung Paceklik setiap anggota memiliki kesempatan yang sama untuk memperoleh pinjaman gabah. Kenyataanya, terdapat pembedaan antara anggota lama dengan anggota baru, yaitu mengenai jumlah gabah yang dapat dipinjam. Berdasarkan informasi yang diperoleh, dapat disimpulkan bahwa kesetaraan menajdi salah satu karakteristik dalam pengelolaan Lumbung Paceklik Desa Dempel mesikpun terdapat sedikit pembedaan. Pembedaan yang dimaksud bukan untuk memberi jarak antar anggota, namun lebih kepada aspek keadilan yang proporsional dan juga demi alasan pengendalian internal yang pada akhirnya kembali kepada manfaat yang lebih besar bagi para anggota.

\section{Efektifitas dan Efisiensi}

Efektifitas dan efisiensi dalam pengelolaan Lumbung Desa Paceklik berarti dalam segala kegiatan pengelolaan lumbung harus memberi manfaat sesuai apa yang diharapkan masyarakat Dempel, khususnya anggota dengan menggunakan sumber daya yang dimiliki secara optimal. Sumber pemasukan utama dari lembaga lumbung adalah bunga pinjaman gabah yang berupa gabah. Sumber pemasukan inilah yang menjadi tumpuan 
dalam pengembangan Lumbung Desa Paceklik Desa Dempel yang harus dikelola secara efisien dan efektif.

Untuk menuju pengelolaan yang efisien maka pengurus masa bakti 2013-2015 memulai dengan membuat penataan organisasi dan sistem kerja yang lebih terstruktur. Langkah efisiensi yang dilakukan pengurus mencerminkan adanya upaya keberpihakan kepada kepentingan yang lebih besar yaitu mempertahankan dan meningkatkan jumlah gabah yang dapat dipinjam oleh anggota daripada mengeluarkannya dalam jumlah relatif besar hanya untuk membiayai RAT yang substansinya sudah dapat dijalankan dengan cara keterwakilan. Pengurus menyadari, dengan mengundang seluruh anggota (840 orang) maka biaya yang dikeluarkan akan menjadi besar yang pada akhirnya mengurangi aset yang dikelola lumbung.

Biaya untuk Rapat Anggota Tahunan yang disajikan dalam Laporan Pertanggungjawaban periode 2013 disebutkan sebesar Rp1.500.000,00 (Tabel 5) untuk 60 orang undangan. Artinya jika menghadirkan seluruh anggota yang berjumlah 840, maka pengurus harus menyediakan dana dari aset lumbung yang nilainya kurang lebih Rp21.000.000,00 atau setara dengan gabah 4,67 ton dengan nilai rupiah Rp4.500/kg. Tidak menghadirkan seluruh anggota tentunya tidak mengurangi esensi dari pelaporan pertanggungjawaban, karena pada dasarnya pengurus melaporkan pertanggungjawaban pengelolaan di hadapan para anggota yang dianggap sebagai tokoh masyarakat di dusundusun yang ada di Desa Dempel. Para tokoh masyarakat inilah yang nantinya diharapkan dapat berperan dalam menyebarluaskan informasi kepada seluruh anggota secara lisan dan dengan bahasa penjelasan yang dapat lebih dimengerti oleh anggota lainnya. Sistem keterwakilan dalam menghadirkan anggota untuk rapat anggota tahunan selain untuk efisiensi juga untuk efektivitas karena menurut pengurus, informasi dapat disebarkan melalui komunikasi berantai dari satu orang ke orang lain yang disebut gethok tular. Informasi tersebut di atas menjelaskan bahwa pengelolaan Lumbung Paceklik berupaya semaksimal mungkin untuk efisien dan efektif.

Tabel 5

Laporan Kas Operasional Tahun 2013

\begin{tabular}{llrrr}
\hline A. & Pemasukan & & & \\
1. Sisa kas tahun lalu & $:$ & $\mathrm{Rp}$ & $449.750,-$ \\
2. $\quad$ Terima dana operasional & $:$ & $\mathrm{Rp}$ & $4.375 .000,-$ \\
3. Uang buku & $:$ & $\mathrm{Rp}$ & $94.000,-$ \\
4 Uang pisang & Jumlah & $:$ & $\mathrm{Rp}$ & $30.000,-$ \\
& & $:$ & $\mathrm{Rp}$ & $4.948 .750,-$ \\
B. Pengeluaran & & & \\
1. Biaya RAT & $:$ & $\mathrm{Rp}$ & $1.500 .000,-$ \\
2. Biaya ATK & $:$ & $\mathrm{Rp}$ & $50.000,-$ \\
3. Konsumsi & $:$ & $\mathrm{Rp}$ & $126.200,-$ \\
4. Pengungsian banjir & $:$ & $\mathrm{Rp}$ & $449.250,-$ \\
& Sisa Kas Operasional & $:$ & $\mathrm{Rp}$ & $2.823 .300,-$ \\
\hline
\end{tabular}




\begin{abstract}
Akuntabilitas
Akuntabilitas diartikan bahwa para pengambil keputusan dalam hal ini pengurus Lumbung Paceklik bertanggung jawab kepada anggota maupun para pemangku kepentingan lainnya. Salah satu cara yang dilakukan pengurus adalah menyelenggarakan RAT yang di dalamnya diagendakan laporan pertanggungjawaban pengurus selama satu tahun kepengurusan kepada para pemangku kepentingan. RAT Lumbung Paceklik dilaksanakan pada tanggal 4 Februari 2014 dengan mengundang 60 orang perwakilan anggota.
\end{abstract}

\title{
Visi Strategis
}

Pengurus dan seluruh pemangku kepentingan memiliki visi strategis yang sangat peduli terhadap eksistensi Lumbung Paceklik. Kepedulian tersebut diwujudkan dengan merencanakan dan mengupayakan pemindahan bangunan lumbung sebagai tempat penyimpanan gabah ke tempat yang lebih aman dari ancaman banjir. Bencana banjir dapat menyebabkan gabah yang disimpan dalam lumbung menjadi rusak yang pada akhirnya mengancam eksistensi Lumbung Paceklik.

\section{ANALISIS DAN PEMBAHASAN}

\section{Akuntabilitas Lumbung Desa Paceklik}

Menurut informasi yang diperoleh di lapangan, akuntabilitas dimaknai sebagai kebutuhan utama dalam mengelola dan memajukan lumbung. Pengurus sangat menyadari bahwa modal utama dari keberhasilan pengelolaan adalah kepercayaan dari para anggota, yaitu semangat mengembalikan pinjaman dan mencegah pinjaman macet. Untuk memperoleh kepercayaan tersebut, akuntabilitas menjadi isu penting yang harus dijawab oleh pengurus dengan pengelolaan yang terukur dan dapat dipertanggungjawabkan.

Persepsi masyarakat terhadap kepengurusan Lumbung Paceklik periode 2013 dibangun dengan baik salah satunya adalah dengan menunjuk orang-orang yang dianggap mampu dan mau dalam mengelola lumbung. Pengurus yang ditunjuk paling tidak harus memiliki profil yang bagus di mata masyarakat Desa Dempel yaitu jujur, cakap, disiplin dan dapat menjadi contoh yang baik bagi masyarakat.

\footnotetext{
"Pengurus itu kan dipilih saat rapat anggota, dan memilih orang itu dipilah dulu siapa kira-kira yang tepat, baru dipilih. Pelaporan dan sosok pengurus sama pentingnya, karena sebuah laporan itu jelas validnya pada saat orang-orangnya pun juga mampu membuat laporan. Ketika orang yang sangat baik tetapi tidak bisa membuat laporan dan menyampaikan kepada orang lain kan akan percuma saja." (Hasil wawancara dengan informan lainnya tanggal 22 Desember 2013).
}

Informasi dari informan di atas menjelaskan bahwa profil kepengurusan merupakan titik awal yang harus dipenuhi untuk mencapai pengelolaan Lumbung Paceklik yang baik. Akuntabilitas Lumbung Paceklik akan lebih berarti ketika persepsi masyarakat Desa Dempel sejalan dengan harapan pengurus, yaitu dipercaya dan 
mendapat dukungan. Langkah selanjutnya dalam mewujudkan akuntabilitas adalah dengan membangun sistem kerja yang terstruktur, terencana dan konsisten, salah satunya adalah dengan mendisiplinkan sistem pembukuan dan transaksi.

\begin{abstract}
"Kalau kepengurusan kita saat ini kan gini, kalau buka di meja seperti ini, ada empat orang. Dari penimbang diberi buku, kemudian diserahkan ke saya. Saya masukkan ke catatan. Setelah itu saya masukkan ke buku, kemudian ke Ketua. Ketua mengecek keselurahannya dari awal pinjaman masyarakat, sambil mengkroschekkan ke buku gedhe, lalu setelah ketua sudah deal, masuk ke bendahara untuk dicatat lagi. Jadi pengurus satu, dua, tiga itu mencatat, nanti pada akhir penutupan (jam 07.00 - 10.00 WIB, mau pulang), kita kroschek lagi. Kalau dulu tidak, yang ada penimbang satu, pencatat satu (orang). Setelah dari sana (penimbang), masuk ke (pembukuan), akhirnya di buku masuk (ada buku masuk, buku keluar, dan buku besar), dan buku besar tidak sama. Di buku besar ada, di buku catatan tidak ada. Di buku catatan ada, di buku besar tidak ada, seperti itu. Banyak kasus terjadi, diantaranya saya kasih undangan untuk penagihan, anggota bilang sudah lunas. Saya cari di buku besar tidak ada, saya cari di buku angsuran ada" (Hasil wawancara dengan informan tanggal 7 September 2013).
\end{abstract}

Proses selanjutnya dalam mewujudkan akuntabilitas Lumbung Paceklik adalah pelaporan. Para pengurus mempertanggungjawabkan, menyajikan, melaporkan dan mengungkapkan segala aktivitas dan kegiatan yang menjadi tanggungjawabnya kepada anggota dalam RAT seperti yang disampaikan dalam hasil wawancara berikut ini.

"Kalau tidak ada laporan pertanggungjawaban pada saat RAT ya jatuh kepengurusan kita, yang kita undang anggota yang pokok-pokok, yaitu tokoh masyarakat, nanti secara otomatis akan menyebarkan berita secara gethok tular bagaimana kondisi lumbung yang terbaru. Jadi laporan itu penting, terutama di RAT'. (Pernyataan informan saat wawancara 22 Desember 2013).

Dari beberapa informasi yang telah diperoleh dalam hasil pengamatan dan wawancara dapat disimpulkan bahwa akuntabilitas merupakan suatu kewajiban dan kebutuhan dalam pengelolaan lumbung untuk menumbuhkan rasa kepercayaan, simpati dan dukungan masyarakat terhadap keberadaan Lumbung Paceklik beserta kepengurusan yang menjalankannya. Hal ini akan berdampak pada proses peminjaman dan pengembalian gabah menjadi lancar dan dapat terhindar dari kredit macet yang berakibat terhentinya operasi Lumbung Paceklik.

Akuntabilitas dijalankan dengan menjunjung nilai-nilai kearifan lokal yang berkembang dalam kehidupan masyarakat Desa Dempel yaitu rasa saling memiliki yang tinggi terhadap Lumbung Paceklik. Dengan pandangan tersebut, maka masyarakat baik yang duduk sebagai pengurus maupun anggota akan sama-sama menjaga keberadaan lumbung sebagai suatu kebanggaan seperti yang disampaikan dalam hasil wawancara berikut: ini.

"Dari sini dapat dikatakan bahwa seluruh elemen masyarakat itu merasa memiliki

Lumbung Desa ini, rasa handarbeni-nya ada." (Peryataan informan saat wawancara 22 Desember 2013). 
Pengurus Lumbung Paceklik masa bakti 2013-2014 menyajikan laporan pertanggungjawaban periode 2013 pada tanggal 4 Pebruari 2014. Hal tersebut merupakan wujud implementasi akuntansi dalam pengelolaan lumbung Paceklik yang secara teknis menurut pengurus tidak merepotkan dan memberatkan, serta sangat mudah diimplementasikan seperti yang disampaikan dalam hasil wawancara berikut ini.

"Artinya begini, laporan pertanggungjawaban itu memang ada. Namun bagi kami, ketika laporan itu sudah dapat dikroscekkan atau diuji kebenarannya, itu sudah cukup bagi kami untuk menyampaikan kepada anggota."

“....memang belum ada standar pelaporan seperti koperasi atau sejenisnya. Ketika sudah RAT, maka hasil RAT digunakan sebagai acuan kerja tahun berikutnya”.

(Peryataan informan saat wawancara tanggal 22 Desember 2013).

“....pembukuannya dengan tiga buku tersebut sudah jalan, sangat sederhana dan mudah dicerna, atau mudah diaplikasikan dan mudah dibaca oleh masyarakat.”

"Sementara ini tidak ada kendala, karena mungkin pembukuannya sangat sederhana. Sementara ini belum ada kendala. Mungkin lama-kelamaan pasti itu kan dituntut pembukuan yang lebih."

(Peryataan informan saat wawancara tanggal 24 Nopember 2013).

\section{Akuntansi dalam Lumbung Desa Paceklik}

Akuntansi didefinisikan dari dua sudut pandang, yaitu sudut pandang pemakai jasa akuntansi dan sudut pandang proses kegiatannya (Jusup 2001). Pengurus menginformasikan dan melaporkan kepada anggota tentang pengelolaan Lumbung Paceklik yang di dalamnya mencakup informasi mengenai gabah yang dikumpulkan selama periode tahun 2013, gabah yang dikeluarkan atau dipinjamkan kepada anggota pada periode pengeluaran tahun 2013, data aset serta pengeluaran-pengeluaran biaya yang terjadi selama periode tersebut.

Laporan yang disajikan pada saat RAT merupakan titik awal anggota untuk melakukan evaluasi. Anggota dapat melakukan evaluasi mengenai substansi maupun kebenaran laporan tersebut dan selanjutnya memutuskan apakah laporan keuangan yang merupakan bagian dari laporan pertanggungjawaban pengurus Lumbung Paceklik periode 2013 tersebut diterima atau ditolak. Hasil RAT yang diselenggarakan pada tanggal 4 Februari 2014 menyatakan bahwa laporan keuangan tersebut diterima oleh anggota, seperti yang diinformasikan pengurus berikut:

“...... dan Alhamdulillah laporan pertanggungjawaban kita diterima."

(Pernyataan informan saat wawancara tanggal 02 Maret 2014)

Setelah melakukan evaluasi atas laporan pertanggungjawaban tersebut, anggota sebagai pengguna utama laporan keuangan Lumbung Paceklik memberikan rekomendasi yaitu menunda penambahan anggota baru dengan alasan kekhawatiran jumlah gabah yang tidak mencukupi serta pemindahan lumbung ke tempat yang lebih aman dari 
ancaman banjir. Berdasarkan informasi sebelumnya, dapat disimpulkan bahwa dari sudut pandang pemakai jasa akuntansi, anggota Lumbung Paceklik telah menggunakan laporan keuangan yang disajikan pengurus sebagai dasar untuk melakukan evaluasi dan menilai pertanggungjawaban, apakah diterima atau ditolak serta memberikan rekomendasi untuk periode selanjutnya.

Dalam konteks Lumbung Paceklik, kegiatan akuntansi dilakukan dengan melakukan pencatatan atas transaksi yaitu peminjaman dan pengembalian pinjaman dalam buku yang berbeda. Kemudian dirangkum dalam buku induk, atau oleh pengurus disebut buku kas atau buku gedhe seperti yang disampaikan dalam kutipan wawancara berikut ini.

\begin{abstract}
"Bukunya sekarang ini terdiri dari buku induk atau disebut juga buku kas, buku pemasukan, dan buku pengeluaran. Buku pemasukan digunakan untuk mencatat pengembalian gabah yang dipinjam anggota. Buku pengeluaran digunakan untuk mencatat peminjaman gabah oleh anggota. Jadi setelah kita bukukan pada buku pemasukan, selanjutnya kita salin ke buku kas atau buku induk yang merangkap buku kas. Pembukuannya dengan tiga buku tersebut sudah jalan, sangat sederhana dan mudah dicerna, atau mudah diaplikasikan dan mudah dibaca oleh masyarakat." (Hasil wawancara dengan informan tanggal 24 Nopember 2013).
\end{abstract}

Secara umum implementasi akuntansi dalam pengelolaan Lumbung Paceklik telah dijalankan, hanya saja dengan berbagai keterbatasan yang ada dan pragmatisme pengurus, maka laporan keuangan disajikan sesuai dengan kemampuan pengurus. Hasilnya kebermanfaatan informasi akuntansi tidak maksimal. Informasi yang disajikan tidak dapat digunakan untuk melakukan analisis melalui penghitungan rasio-rasio karena pelaporan masih menggunakan satuan yang belum ditranslasikan dalam bentuk moneter serta menggunakan satuan ganda yaitu mata uang dan kilogram. Kekurangan yang ada, pada dasarnya telah disadari oleh pengurus seperti yang dinyatakan dalam wawancara berikut ini.

\footnotetext{
"Iya mas, dengan akuntansi hasilnya dapat terukur. Kalau kita selama ini laporannya juga seperti itu mas. Jadi karena dulu itu kan kita tahu yang kita pinjamkan sekian, terus jangka waktu setahun yang masuk sekian, nah labanya sekian, dikurangi penyusutan gabah, baru kita ketahui laba bersih. Laba bersih dikurangi berapa persen untuk honor pengurus, berapa persen untuk pemeliharaan. Karena sekarang kondisinya hanya narik, butuhe nglebokke, jadi fokusnya mengumpulkan." (Pernyataan informan saat wawancara tanggal 07 September 2013).
}

\title{
SIMPULAN, KETERBATASAN DAN SARAN
}

Lumbung Paceklik merupakan wujud kearifan lokal masyarakat Desa Dempel hingga kini masih dipertahankan yang didasarkan pada pengelolaan Lumbung Paceklik dan dijalankan sesuai dengan karakteristik governance yang disebutkan UNDP (Mardiasmo 2002). Adanya permasalahan mengenai bentuk badan hukum yang sesuai dengan karakteristik Lembaga Lumbung Paceklik harus segera ditindaklanjuti agar memudahkan pengelolaannya dan juga memudahkan dalam melakukan aktivitas hukum 
dengan subyek hukum lainnya. Alternatif dari bentuk badan hukum yang ditawarkan oleh peneliti adalah Badan Keswadayaan Masyarakat (BKM).

Akuntansi dalam Lumbung Paceklik dimaknai dan dijalankan sebagai alat ukur akuntabilitas. Dalam implementasinya, akuntansi tidak dilaksanakan secara maksimal karena keterbatasan pemahaman dan kemampuan pengurus dalam mencatat, menggolongkan, meringkas dan melaporkan data keuangan. Akibat dari keterbatasan tersebut, laporan yang disajikan jika dilakukan analisa belum dapat memberikan informasi yang lebih bernilai yang menggambarkan keadaan sebenarnya dari Lumbung Paceklik. Hal ini perlu adanya perhatian lebih dari pemerintah terkait dengan pembinaan dan pegembangan lumbung desa, terutama Lumbung Paceklik. Partisipasi para ilmuwan di bidang akuntansi juga diharapkan untuk ikut berperan dalam melakukan pendampingan mengenenai penyusunan laporan keuangan yang baik sesuai dengan prinsip akuntansi berterima umum.

Karakteristik governance yang digunakan untuk mengamati tata kelola Lumbung Desa pada penelitian ini hanya terbatas pada karakteristik yang dinyatakan UNDP. Karakteristik tersebut hanya dilihat dari definisinya saja dan belum melihat pada indikator serta alat ukur yang jelas. Karakteristik governance tentunya masih sangat luas dan terus berkembang, terutama yang dapat dikaitkan dengan tata kelola organisasi publik nonpemerintah seperti Lumbung Desa. Penelitian lanjutan masih diperlukan dengan menambah obyek penelitian yang memiliki karakteristik yang sama sehingga dapat diperoleh informasi yang lebih lengkap dan nyata mengenai Lembaga Lumbug Desa.

\section{DAFTAR PUSTAKA}

Badan Pengawas Keuangan dan Pembangunan. 2007. "Akuntabilitas instansi pemerintah."

Bungin, Burhan. 2011. Penelitian kualitatif: Komunikasi, ekonomi, kebijakan publik, dan ilmu sosial lainnya. 2ed. Jakarta: Prenada Media Group.

Cahyanto, Sugeng Setya, Bonifasius S.P, dan Ataabik Mutaman. 2012. "Penguatan kearifan lokal sebagai solusi permasalahan ketahanan pangan nasional." In The 4th International Conference on Indonesian Studies, 1-18.

Costa, Ericka, Tommaso Ramus, dan Michele Andreaus. 2011. "Accountability as a managerial tool in non-profit organizations: Evidence from Italian CSVs." Voluntas 22 (3): 470-93. https://doi.org/10.1007/s11266-011-9183-7.

Creswell, John W. 2012. Research design: Pendekatan kualitatif, kuantitatif dan mixed. 3ed. Yogyakarta: Pustaka Pelajar.

Duncan, John B., dan Dale L. Flesher. 2002. "Does your church have appropriate internal control for cash receipts?" National Public Accountant, 2002.

Gray, Rob, Jan Bebbington, dan David Collison. 2006. "NGOs, civil society and 
accountability: Making the people accountable to capital." Accounting, Auditing and Accountability Journal $19 \quad 319-48$. https://doi.org/10.1108/09513570610670325.

Hartatik, Endah. 2010. "Pembentukan lembaga lumbung desa di grobogan pada awal abad xx." Paramita 20 (1): 36-44.

Johnson, Doyle Paul. 1986. Teori sosiologi klasik dan modern. Jakarta: Gramedia Pustaka Utama.

Jusup, Al Haryono. 2001. Dasar-dasar akuntansi jilid 1. Yogyakarta: STIE YKPN.

Kartawinata, Ade M. 2011. "Pengantar editor merentas kearifan lokal di tengah moderanisasi dan tantangan pelestarian." In Kearifan Lokal di tengah Moderanisasi, v-xviii. Kementerian Kebudayaan dan Pariwisata Republik Indonesia.

Laughlin, Richard C. 1988. "Accounting in its social context: An analysis of the accounting systems of the church of England." Accounting, Auditing \& $\begin{array}{llll}\text { Accountability } & \text { Journal } & 1 & \text { (2): }\end{array}$ https://doi.org/10.1108/EUM0000000004622.

- 1990. "A model of financial accountability and the church of England." Financial Accountability and Management 6 (2): 93-114. https://doi.org/10.1111/j.1468-0408.1990.tb00427.x.

Lembaga Adminitrasi Negara. 2000. "Akuntabilitas dan good governance."

Maksum, Azhar. 2005. "Tinjauan atas good corporate governance di Indonesia." In Pidato Pengukuhan Guru Besar Tetap Universitas Sumatera Utara, 1-55. Medan.

Mardiasmo. 2002. Akuntansi Sektor Publik. Yogyakarta: Andi Publisher.

Noval, M. 2002. "Studi eksistensi lumbung desa." Badan Penelitian dan Pengembangan Departemen Dalam Negeri, 2002.

Nugrahanto, Widyo, N. Kartika, dan Tanti Restiasih Skober. 2008. "Perkreditan rakyat di Tasikmalaya pada masa pemerintahan Hindia Belanda dan Republik Indonesia (1900-2003)." Lembaga Penelitian Universitas Padjajaran. 2008.

Pemerintah Republik Indonesia. 2014. "Undang-undang nomor 6 tahun 2014 tentang desa."

Salam, Aprinus. 2006. "Perubahan sosial dan pertanyaan tentang kearifan lokal." In Workshop SP4 Jurusan Sastra Indonesia, 1-11. Yogyakarta.

Sartini, S. 2004. "Menggali kearifan lokal nusantara sebuah kajian filsafati." Jurnal Filsafat 37 (2): 111-20. https://doi.org/10.22146/jf.31323.

Simatupang, P. 1999. "Toward sustainable food security: The need for a new paradigm." 
In International Seminar on Agricultural Sector During the Turbulence of Economic Crisis: Lesson and Future Direction. Bogor: ICASERD.

Soemaryani, Imas, Kartib, dan Heru Setiawan. 2009. "Model pengembangan sistem pangan komunitas lokal melalui revitalisasi lumbung desa dalam mendukung ketahanan pangan rumah tangga di pedesaan.” DRPMI Universitas Padjajaran. 2009.

Wasino, H. 2004. “Tilak, pedagang pengumpul hasil pertanian pedesaan jawa, studi kasus wanita pedagang di kecamatan Wirosari, Kabupaten Grobogan.”

Wasino, H., S. Endah, R. Iswari, dan Sriwahyuningsih. 2007. "Revitalisasi dan modifikasi lumbung desa sebagai wahana ketahanan pangan berbasis masyarakat di kabupaten Grobogan Jawa Tengah.”

Wibowo, A., Sugihardjo, dan H. Ihsaniyati. 2007. "Kemiskinan penduduk sekitar waduk kedung ombo: Studi kasus di desa Watugede Kecamatan Kemusu Kabupaten Boyolali." Jurnal Penduduk \& Pembangunan 7 (1): 27-35.

Wiradi, G. 1985. "Lumbung desa mungkinkan dihidupkan kembali." Kompas, Maret 1985.

Yanto, T. 1994. "Studi profil lumbung desa di desa tertinggal dan desa tidak tertinggal, studi kasus di Kabupaten Purbalingga." Institut Pertanian Bogor. 


\section{Lampiran: Laporan Keuangan Lumbung Desa Paceklik Periode 2013}

Tabel 1

Laporan Pemasukan Padi Tahun 2013 (Kg)

\begin{tabular}{|c|c|c|c|c|c|}
\hline \multirow{2}{*}{ Dusun } & \multicolumn{4}{|c|}{ Musim } & \multirow{2}{*}{ Jumlah } \\
\hline & Rendeng & Gadu & Apitan & Sisa 2012 & \\
\hline Sisa & - & - & - & 487 & 487 \\
\hline Dempel & 8.406 & 3.607 & 3.890 & - & 15.903 \\
\hline Nglencong & 9.207 & 4.040 & 5.478 & - & 18.725 \\
\hline Gunting & 6.989 & 2.424 & 2.595 & - & 12.008 \\
\hline Jumlah & 24.602 & 10.071 & 11.963 & 487 & 47.123 \\
\hline
\end{tabular}

Tabel 2

Laporan Pengeluaran Gabah $(\mathrm{Kg})$

\begin{tabular}{lrrrrrrr}
\hline \multicolumn{1}{c}{ Dusun } & $\begin{array}{c}\text { Dipinjam } \\
\text { Anggota }\end{array}$ & Bangunan & BOP & Honor & Susutan & Sisa & Jumlah \\
\hline Sisa & - & - & - & - & - & & \\
Dempel & 5.450 & 333,5 & 333,5 & 892 & 199,5 & $8.694,5$ & 15.903 \\
Ngelcong & 8.025 & 333,5 & 333,5 & $1.109,5$ & 235,0 & $8.688,5$ & 18.725 \\
Gunting & 5.450 & 333,0 & 333,0 & 592,5 & 150,5 & $5.149,0$ & 12.008 \\
Jumlah & 18.9225 & 1.000 & 1.000 & 2.594 & 585,0 & 23.019 & 47.123 \\
\hline
\end{tabular}
Sumber: LPJ Lumbung Padi Paceklik Desa Dempel Tahun 2013

Tabel 3

Laporan Data Aset (Kg)

\begin{tabular}{lrrrrr}
\hline \multicolumn{1}{c}{ Dusun } & Dipinjam Anggota & Rencana Bunga & \multicolumn{1}{c}{ Sisa } & Tunggakan & Jumlah \\
\hline Sisa & - & - & 487,0 & - & 487,0 \\
Dempel & 5.450 & 1.090 & $8.694,5$ & $21.290,0$ & $36.524,5$ \\
Nglencong & 8.025 & 1.605 & $8.688,5$ & $21.406,5$ & $39.725,0$ \\
Gunting & 5.450 & 1.090 & 5.149 & $13.052,0$ & $24.741,0$ \\
Jumlah & 18.925 & 3.785 & 23.019 & $55.748,5$ & $101.477,5$ \\
\hline
\end{tabular}

Sumber: LPJ Lumbung Padi Paceklik Desa Dempel Tahun 2013 
Laporan Kas Bangunan Tahun 2013

\begin{tabular}{lllll}
\hline A. Pemasukan & & & \\
1. Terima Uang dari banguna 1 ton gabah & $:$ & $\mathrm{Rp}$ & $4.375 .000,-$ \\
B. Pengeluaran & $:$ & $\mathrm{Rp}$ & $695.000,-$ \\
1. Perbaikan Lumbung & $:$ & $\mathrm{Rp}$ & $500.000,-$ \\
2. PAD (Pendapatan Asli Desa) SISA KAS BANGUNAN & $:$ & $\mathrm{Rp}$ & $3.180 .000,-$ \\
\hline
\end{tabular}
Sumber: LPJ Lumbung Padi Paceklik Desa Dempel Tahun 2013 